\title{
Temporal proteomic profiling reveals insight into critical developmental processes and temperature-influenced physiological response differences in a bivalve mollusc
}

Shelly A. Trigg ${ }^{1 *}$ D, Kaitlyn R. Mitchell1', Rhonda Elliott Thompson', Benoit Eudeline², Brent Vadopalas ${ }^{3}$, Emma B. Timmins-Schiffman ${ }^{4}$ and Steven B. Roberts ${ }^{1}$

\begin{abstract}
Background: Protein expression patterns underlie physiological processes and phenotypic differences including those occurring during early development. The Pacific oyster (Crassostrea gigas) undergoes a major phenotypic change in early development from free-swimming larval form to sessile benthic dweller while proliferating in environments with broad temperature ranges. Despite the economic and ecological importance of the species, physiological processes occurring throughout metamorphosis and the impact of temperature on these processes have not yet been mapped out.

Results: Towards this, we comprehensively characterized protein abundance patterns for 7978 proteins throughout metamorphosis in the Pacific oyster at different temperature regimes. We used a multi-statistical approach including principal component analysis, ANOVA-simultaneous component analysis, and hierarchical clustering coupled with functional enrichment analysis to characterize these data. We identified distinct sets of proteins with time-dependent abundances generally not affected by temperature. Over 12 days, adhesion and calcification related proteins acutely decreased, organogenesis and extracellular matrix related proteins gradually decreased, proteins related to signaling showed sinusoidal abundance patterns, and proteins related to metabolic and growth processes gradually increased. Contrastingly, different sets of proteins showed temperature-dependent abundance patterns with proteins related to immune response showing lower abundance and catabolic pro-growth processes showing higher abundance in animals reared at $29^{\circ} \mathrm{C}$ relative to $23^{\circ} \mathrm{C}$.
\end{abstract}

(Continued on next page)

* Correspondence: strigg@uw.edu

'School of Aquatic and Fishery Sciences, University of Washington, Seattle, Washington 98105, USA

Full list of author information is available at the end of the article

(c) The Author(s). 2020 Open Access This article is licensed under a Creative Commons Attribution 4.0 International License, which permits use, sharing, adaptation, distribution and reproduction in any medium or format, as long as you give appropriate credit to the original author(s) and the source, provide a link to the Creative Commons licence, and indicate if changes were made. The images or other third party material in this article are included in the article's Creative Commons licence, unless indicated otherwise in a credit line to the material. If material is not included in the article's Creative Commons licence and your intended use is not permitted by statutory regulation or exceeds the permitted use, you will need to obtain permission directly from the copyright holder. To view a copy of this licence, visit http://creativecommons.org/licenses/by/4.0/ The Creative Commons Public Domain Dedication waiver (http://creativecommons.org/publicdomain/zero/1.0/) applies to the data made available in this article, unless otherwise stated in a credit line to the data. 


\begin{abstract}
(Continued from previous page)
Conclusion: Although time was a stronger driver than temperature of metamorphic proteome changes, temperature-induced proteome differences led to pro-growth physiology corresponding to larger oyster size at $29^{\circ} \mathrm{C}$, and to altered specific metamorphic processes and possible pathogen presence at $23^{\circ} \mathrm{C}$. These findings offer high resolution insight into why oysters may experience high mortality rates during this life transition in both field and culture settings. The proteome resource generated by this study provides data-driven guidance for future work on developmental changes in molluscs. Furthermore, the analytical approach taken here provides a foundation for effective shotgun proteomic analyses across a variety of taxa.
\end{abstract}

Keywords: Proteomics, Time-series, Developmental physiology, Oyster, Temperature, Mollusc

\section{Background}

The Pacific oyster (Crassostrea gigas) is among the most ecologically and economically prominent bivalve molluscs given its contribution to biofiltration, habitat formation and stabilization, carbon and nitrogen sequestration, and international aquaculture revenue $(\sim$ $\$ 1.25$ billion annually [1]). From a developmental perspective, it is a fascinating organism as it undergoes a complex transformation from a free-swimming planktonic larva to a sessile benthic juvenile. This involves two processes: settlement and metamorphosis. Once oysters acquire the ability to initiate and undergo morphogenesis (become competent), settlement commences typically 24 to $48 \mathrm{~h}$ later where larvae drop out of the water column to the benthos, and use a newly developed foot to find appropriate substrate and secrete adhesive to attach to the substrate $[2,3]$. Then, metamorphosis typically occurs within a few to $72 \mathrm{~h}$ and involves a complete rearrangement of organs, loss of larval organs including the velum and the foot, and development of new organs including gill-like ctenidia $[4,5]$. Complex physiology underlies both of these processes, involving neuroendocrine and immune functions and tightlycontrolled gene expression programs, which is still not fully understood [6].

In addition to the physiological complexities of settlement and metamorphosis, the Pacific oyster is sensitive to abiotic and biotic factors during this particular life stage with substantial mortality occurring in both field and culture settings [4]. Past studies found that increased rearing temperature positively influenced survival with Pacific oyster larvae reared at $23^{\circ} \mathrm{C}$ leading to optimal recruitment success [7-9], and established $23^{\circ} \mathrm{C}$ as the standard aquaculture industry rearing temperature [10]. Yet hatcheries still frequently observe stochastic high mortality during this life stage. C. gigas has been observed to tolerate temperatures up to $37^{\circ} \mathrm{C}$ with $100 \%$ survival [11], and their extremely eurythermic trait has enabled their global distribution and culturing on nearly every continent including equatorial islands [12]. Particularly larvae and juveniles have been observed to tolerate temperatures up to $32{ }^{\circ} \mathrm{C}$ when food is not limiting, with maximum growth rates and survival during settlement occurring above $27^{\circ} \mathrm{C}$ [13-16]. To better understand how temperature influences critical developmental processes and phenotype throughout metamorphosis, a comprehensive characterization of developmental physiological processes that occur throughout this life stage is needed.

Proteomics, a survey of the collection of all proteins and their abundances at a given time, is ideally suited to provide a basis for revealing the physiological complexities of development [17]. Specifically, untargeted shotgun proteomic profiling using liquid chromatography coupled tandem mass spectrometry (LC-MS/MS) can efficiently and accurately predict protein abundances by taking into account peptide count, spectral count and fragment-ion intensity [18]. LC-MS/MS has been effectively used to examine changes in biological processes during early larval development in bivalve molluscs prior to metamorphosis $[19,20]$. A two sample proteomic comparison of larvae just prior to metamorphosis with juveniles weeks after metamorphosis showed differences in proteins involved in tissue remodeling, signal transduction, and organ development, however the two proteomes had relatively low coverage (392 and 636 proteins, respectively) [21]. The proteomes of larvae just prior to metamorphosis held at $30^{\circ} \mathrm{C}$ showed changes that correlated with increased growth and calcification [22]. Nevertheless, deeper proteomic profiling of a broader sampling throughout metamorphosis and including temperature as a factor would bring more resolution to physiological processes occurring over time and those affected by temperature. Although untargeted large-scale multi-factor proteome studies pose the challenge of identifying core biological responses in the accompanying large complex datasets, applying multiple statistical approaches can reduce complexity of a large dataset to identify potential targets for diagnostics $[23,24]$. New analyses have been developed to consider temporal influences on multivariate datasets (e.g. analysis of variance simultaneous component analysis (ASCA)), and identify features impacted by specific experimental variables [25]. 
To comprehensively characterize developmental physiological processes that occur throughout settlement and metamorphosis in Pacific oyster domesticated in the Pacific Northwest region of the United States, we used LC-MS/MS to generate temporal proteomes from oyster larvae reared at two different temperature regimes to examine the basis for temperature-influenced phenotype differences. We developed an analysis framework that applies multiple statistical approaches to classify temporal and temperature-influenced developmental processes from proteomic responses. This longitudinal proteomic data paired with phenotypic data provide a high resolution perspective of the physiological mechanisms underlying metamorphic stages and how temperature influences them.

\section{Results}

\section{Larval performance and global proteome analysis}

To comprehensively assess proteomes throughout metamorphosis we collected pools of whole animals at seven different time points starting at competency, the time when larvae have the ability to initiate and undergo metamorphosis (Fig. 1a). After 6 days into the temperature treatment, we found minimal difference in the number of settled larvae between temperatures with 297,213 (29.7\%) and 308,989 (30.9\%) larvae settled at $23^{\circ} \mathrm{C}$ and at $29^{\circ} \mathrm{C}$, respectively. However, larvae reared at $29^{\circ} \mathrm{C}$ tended to be larger in size at 24 days postfertilization (dpf) (Fig. 1b, Additional File 1: Supplemental Table 1).

Quantitative time-series proteomic measurements resulted in an average of 95,506 \pm 2624 (s.d.) total acquired spectra per sample, with $32.22 \pm 2.87 \%$ (s.d.) of spectra uniquely mapping to $24,355 \pm 2027$ (s.d.) different peptides. All samples collectively covered 19.6\% (7978 out of 40,637 predicted proteins) of the C.giags Gigaton database [26], with proteomes at each time point consisting of on average $4936 \pm 255$ (s.d.) proteins. Technical replicates from the same time point clustered together and showed less variability than samples from different time points, demonstrating the high reproducibility of our sample preparation and LC MS/MS measurements (Additional File 2: Supplemental Figure 1). There was an average overlap of $84 \pm 3 \%$ of proteins identified in samples from the same time point but different rearing temperature (Fig. 1c, Additional File 3: Supplemental Table 2). A principal components analysis revealed temperature most strongly influenced protein abundance patterns at 21 and $27 \mathrm{dpf}$, while at 23, 25, 29, and $31 \mathrm{dpf}$ temperature had less of an influence (Fig. 2a). From this analysis a total of 70 proteins were identified as top contributors to this temperature-influenced proteomic variation at 21 and $27 \mathrm{dpf}$ by ordering proteins by their greatest magnitude $\mathrm{PC} 1$ and $\mathrm{PC} 2$ loadings values

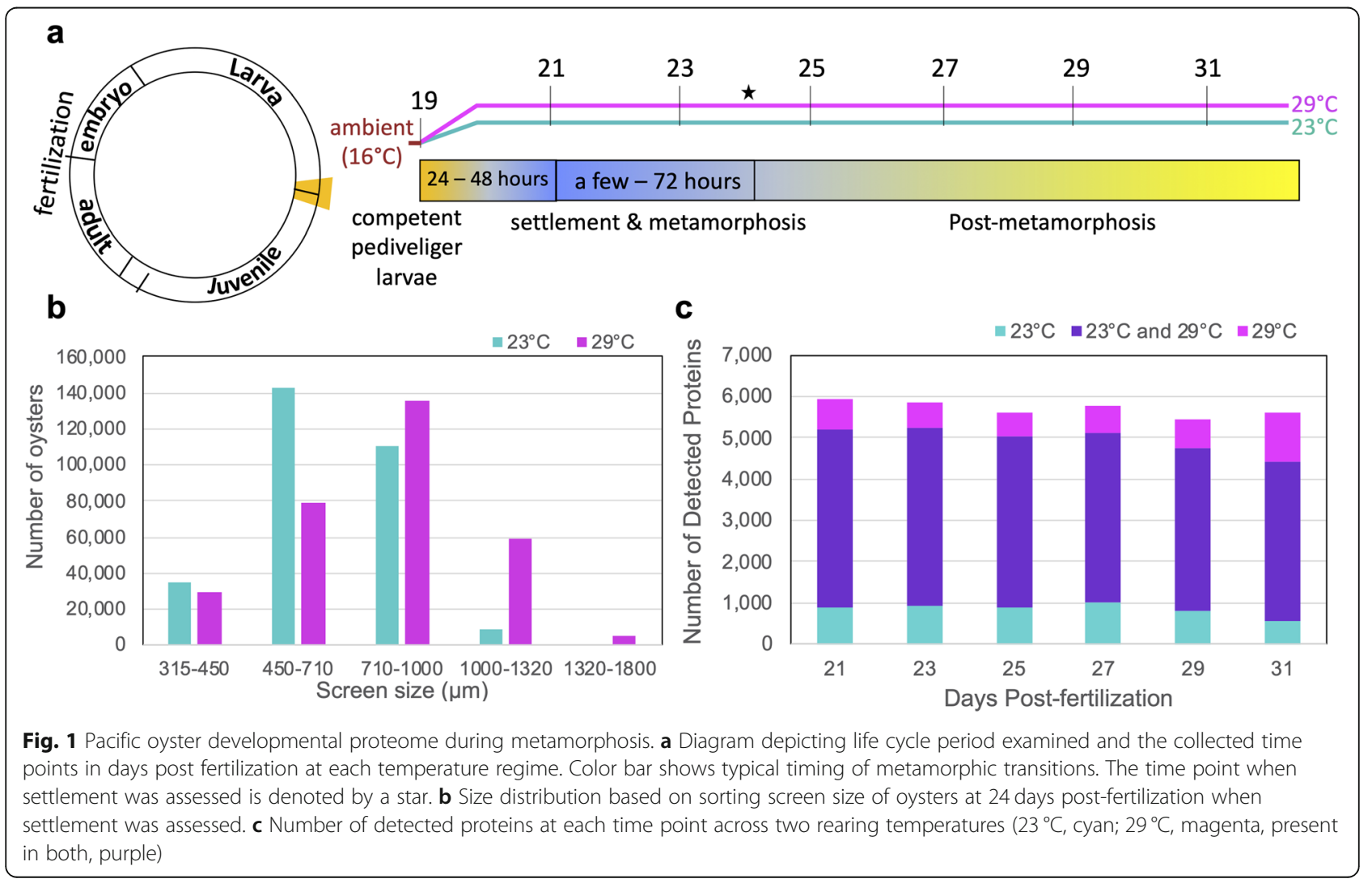




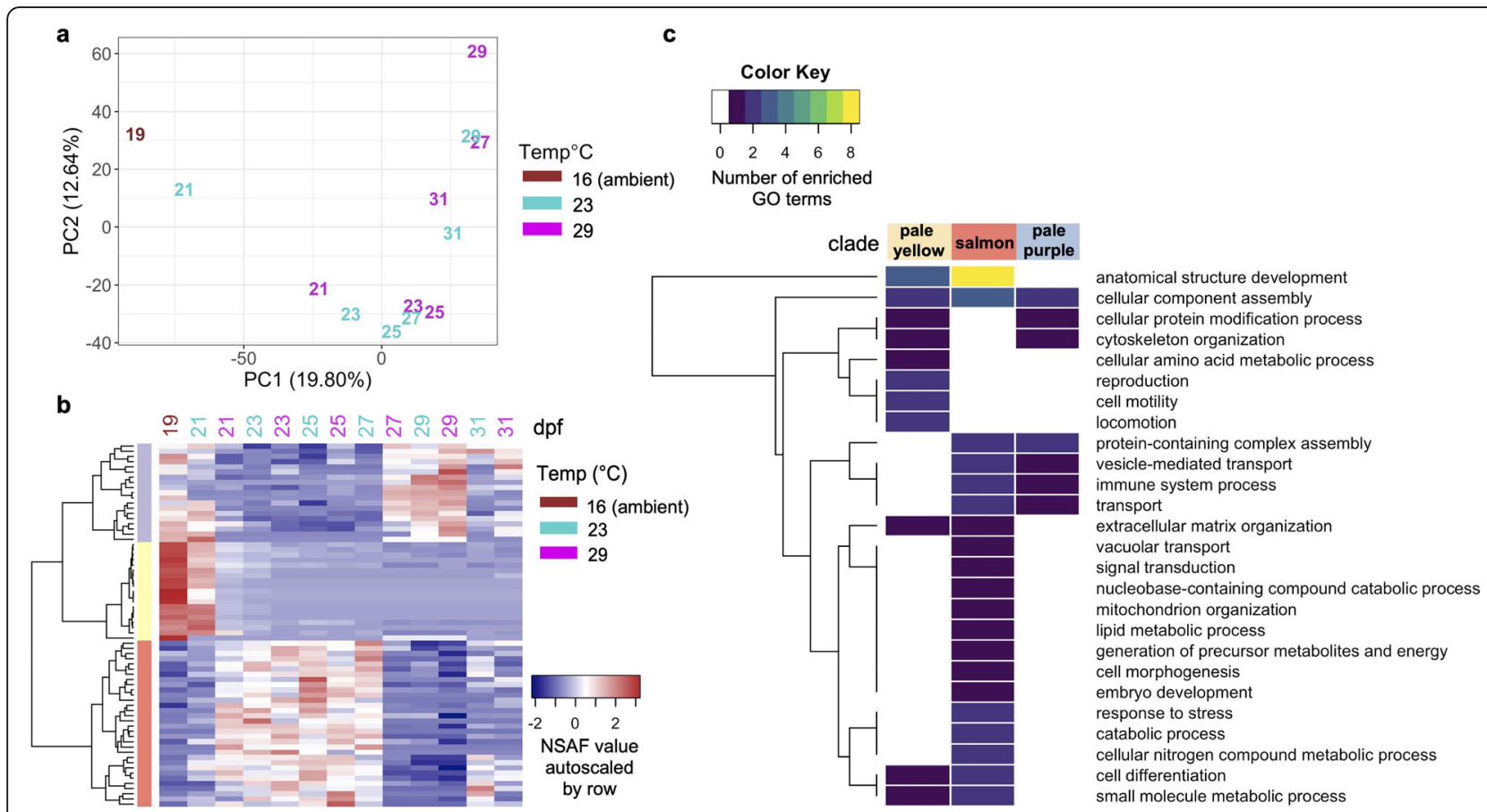

Fig. 2 Temperature most influences 21 and $27 \mathrm{dpf}$ proteomes. a Visualization of the first two principal components from principal component analysis separating samples according to their developmental stage and temperature. Samples are labeled by their sampling time point in days post-fertilization (dpf) with color indicating rearing temperature $\left(16^{\circ} \mathrm{C}\right.$, brown; $23^{\circ} \mathrm{C}$, cyan; $29^{\circ} \mathrm{C}$, magenta). b Protein abundances (NSAF values autoscaled by row) of proteins most influenced by temperature at 21 and $27 \mathrm{dpf}$. c Summary of biological processes represented by enriched $\mathrm{GO}$ terms within each clade for temperature-influenced proteins at 21 and $27 \mathrm{dpf}$

and placing a threshold at the first point with the least visual difference between subsequent loadings values (Additional File 2: Supplemental Figure 2). These proteins showed three general abundance patterns: decreased abundance at $29^{\circ} \mathrm{C}$ relative to $23^{\circ} \mathrm{C}$ at $21 \mathrm{dpf}$ (pale yellow clade), decreased abundance at $29^{\circ} \mathrm{C}$ relative to $23^{\circ} \mathrm{C}$ at $27 \mathrm{dpf}$ (salmon clade), and increased abundance at $29^{\circ} \mathrm{C}$ relative to $23^{\circ} \mathrm{C}$ at $27 \mathrm{dpf}$ (pale purple clade) (Fig. 2b, Additional File 4: Supplemental Table 3). Proteins with decreased abundance at $29^{\circ} \mathrm{C}$ relative to $23^{\circ} \mathrm{C}$ at $21 \mathrm{dpf}$ show significant enrichment of cytoskeleton and extracellular matrix organization, cell motility and locomotion processes (Fig. 2c). Proteins with decreased abundance at $29^{\circ} \mathrm{C}$ relative to $23^{\circ} \mathrm{C}$ at $27 \mathrm{dpf}$ have significant enrichment of early stage development as well as stress response, transport, and catabolic processes, while proteins with increased abundance at $29^{\circ} \mathrm{C}$ relative to $23^{\circ} \mathrm{C}$ at $27 \mathrm{dpf}$ have significant enrichment of cellular component and protein complex assembly, transport, and immune system processes (Fig. 2c).

\section{Time-influenced proteomic variation}

An ANOVA-simultaneous component analysis (ASCA) that partitioned effects from time, temperature, and their interaction revealed that time and the interaction of time and temperature contributed to $91.38 \%$ of the variation in protein abundances (Table 1). However, a permutation test to quantitatively validate ASCA megavariate effects [27] showed that only time had a significant effect on protein abundances (Table 1). In examining the time effect components partitioned by ASCA (Fig. 3a), we found a total of 217 proteins contributed the most to abundance pattern differences across time when proteins were ordered by their time effect $\mathrm{PC} 1$ and $\mathrm{PC} 2$ component loadings values and a threshold was placed at the first point with the least visual difference between subsequent loadings values (Additional File 2: Supplemental Figure 3a-d). Five distinctive clades were identified through cluster analysis of abundance patterns of these time-influenced proteins (Fig. 3b). The identified clades exhibit temporal patterns that appear generally independent of temperature: high abundance early on then acutely reduced (light blue clade), a gradual decrease in abundance over time (purple clade), oscillating

Table 1 Contributions of experimental factors to the ASCApartitioned data variation and permutation validation test results

\begin{tabular}{lll}
\hline Factor & Variation (\%) & $\begin{array}{l}\text { Permutation test } \\
(\boldsymbol{P} \text { value) }\end{array}$ \\
\hline Time & 56.85 & 0.0026 \\
Temperature & 8.56 & 0.1882 \\
Time:Temperature & 34.59 & 0.9981 \\
\hline
\end{tabular}




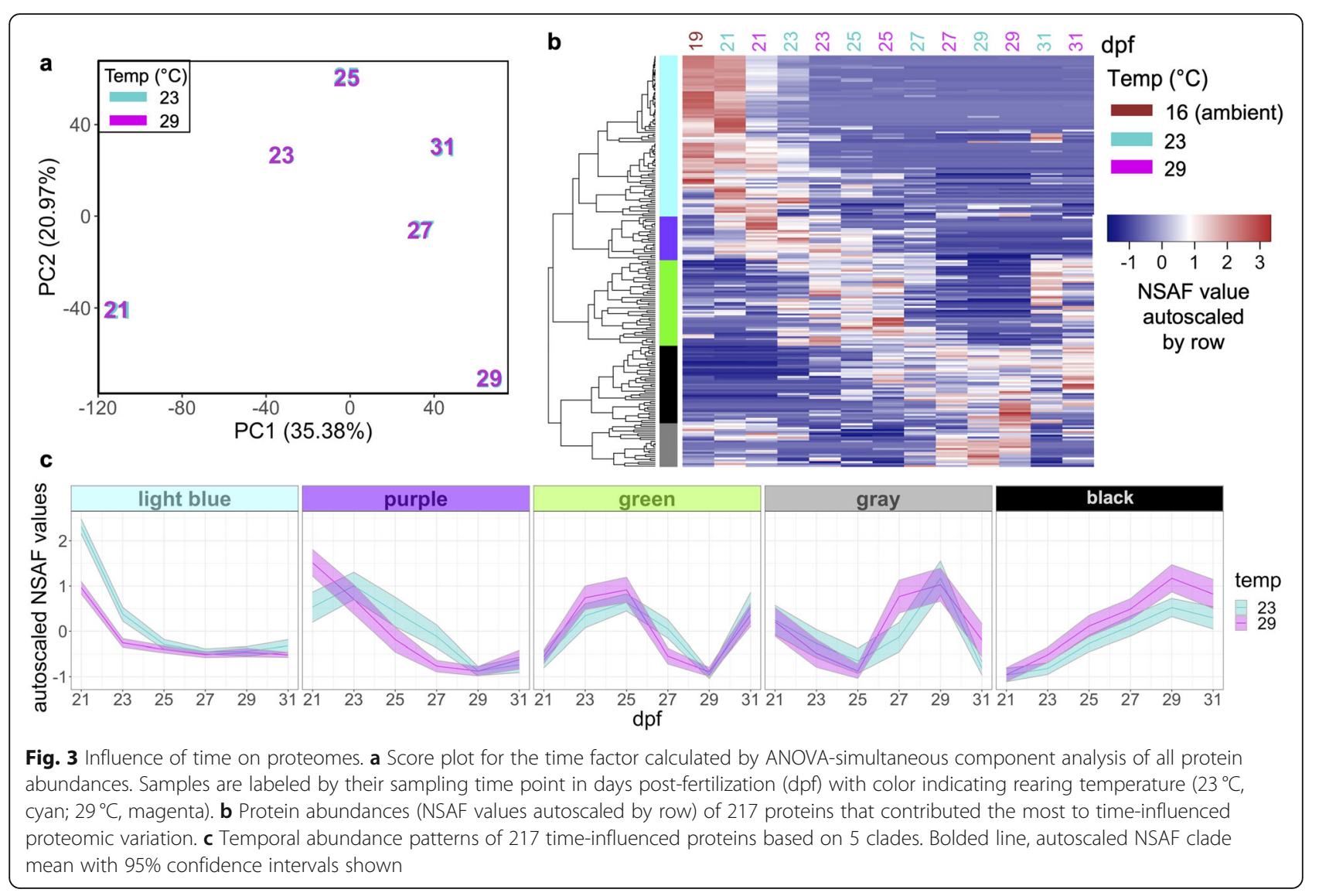

abundance that increases through $25 \mathrm{dpf}$ then decreases through $29 \mathrm{dpf}$ and finally increases again at 31dpf (green clade), oscillating abundance that decreases through $25 \mathrm{dpf}$ then increases through $29 \mathrm{dpf}$ and finally decreases at 31dpf (gray clade), and a gradual increase in abundance over time (black clade) (Fig. 3c).

Biological processes associated with anatomical structure development and cell differentiation were commonly enriched among proteins across most clades, however, there was a distinct set of enriched biological processes for each clade suggesting specific functions for proteins within each clade (Fig. 4, Additional File 5: Supplemental Table 4). Proteins showing high abundance early on then an acute decrease (light blue clade) were related to immune system, stress response, cell proliferation, cell adhesion, nucleocytoplasmic transport, and cellular amino acid metabolism. Proteins showing a gradual decrease in abundance over time (purple clade) were related to cellular component assembly and protein complex assembly processes. Proteins with oscillating abundance that first increases, then decreases, then increases again (green clade) were related to protein modification, stress response, signal transduction, cell death, and transport biological processes. Different than other clades, this clade had more enriched GO terms related to lipid metabolic process, cell death, cellular amino acid metabolic process, locomotion, and cell motility. Proteins with oscillating abundance that first decreases, then increases, then decreases again (gray clade) were associated with cytoskeleton organization, transport (protein localization, lysozyme transport), and morphogenesis. Different than other clades, this clade had more enriched GO terms related to transport (vesicle transport, vacuolar transport), cell-cell signaling, cytoskeleton organization, protein maturation and developmental maturation. Proteins showing a gradual increase over time (black clade) were largely related to growth and development processes, particularly energy-generating glycolytic processes (e.g. fructose metabolism, mannose metabolism, oligosaccharide metabolism, ganglioside catabolism, and adenosine catabolism) and neurogenesis. These proteins had significant enrichment of GO terms related to carbohydrate metabolic process, cofactor metabolic process, generation of precursor metabolites and energy, nervous system process, plasma membrane organization, and nucleobase-containing compound catabolic process. 


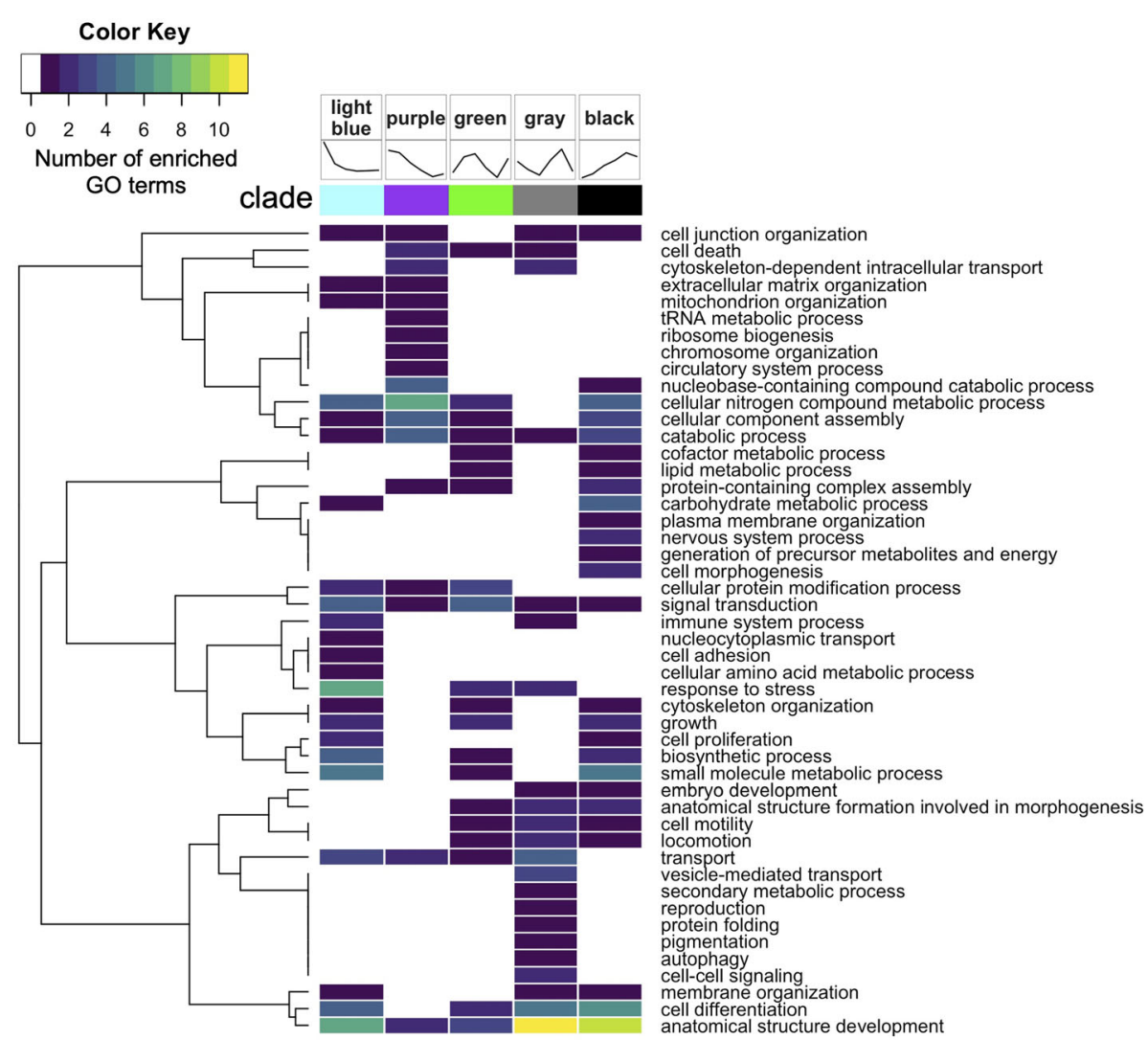

Fig. 4 Summary of biological processes represented by enriched gene ontology terms within each clade for time-influenced proteins

\section{Proteome response to temperature}

Although the ASCA-partitioned effect of temperature was not validated as significant by permutation test (Table 1), we still explored proteins contributing to the ASCA-modeled separation of samples by temperature. In examining the temperature effect component partitioned by ASCA (PC1, Fig. 5a), we found a total of 259 proteins to be significantly influenced by temperature when proteins were ordered by their temperature effect PC1 component loadings values and a threshold was placed at the first point with the least visual difference between subsequent loadings values (Additional File 2: Supplemental Figure 3e-f). Hierarchical clustering of these protein abundance patterns revealed two distinctive clades that generally show increased or decreased abundance in $29^{\circ} \mathrm{C}$ relative to $23^{\circ} \mathrm{C}$ samples throughout time (orange clade and dark teal clade, respectively; Fig. 5b-c, Additional File 6: Supplemental Table 5). Proteins showing increased abundance in $29^{\circ} \mathrm{C}$ relative to $23^{\circ} \mathrm{C}$ (orange clade) were enriched for growth and development related processes while proteins showing decreased abundance in $29^{\circ} \mathrm{C}$ relative to $23^{\circ} \mathrm{C}$ (dark teal clade) were enriched for transport, catabolism, and immune system related processes (Fig. 6). Immune related proteins in the dark teal clade include putative RNA helicase DEAD box proteins 47 and 58 involved in cellular response to exogenous dsRNA and a putative exosome complex component protein involved in RNA degradation; two homologs of Heme-binding protein 2 and a putative Receptor-interacting serine/threonineprotein kinase 1 known to be involved in positive regulation of necrotic cell death; a putative DnaJ Heat Shock Protein Family (Hsp40) Member A3 known to be involved in cell death activation and growth inhibition; a putative cytidine deaminase known to be involved in signaling and growth inhibition; and a putative COMMD9 involved in neutrophil degranulation.

\section{Discussion}

We used time series proteomics to explore how oyster physiology is affected by rearing temperature during metamorphosis, generated comprehensive proteomes at seven different time points and across two different temperatures, and did a comparative analysis of how time and temperature affect proteins and their associated biological processes. Performing ASCA, a method which generalizes analysis of variance to a multivariate case [25], allowed the variation in the proteomic data to be partitioned by the experimental factors of temperature, time and their interaction. From this partitioning, we 


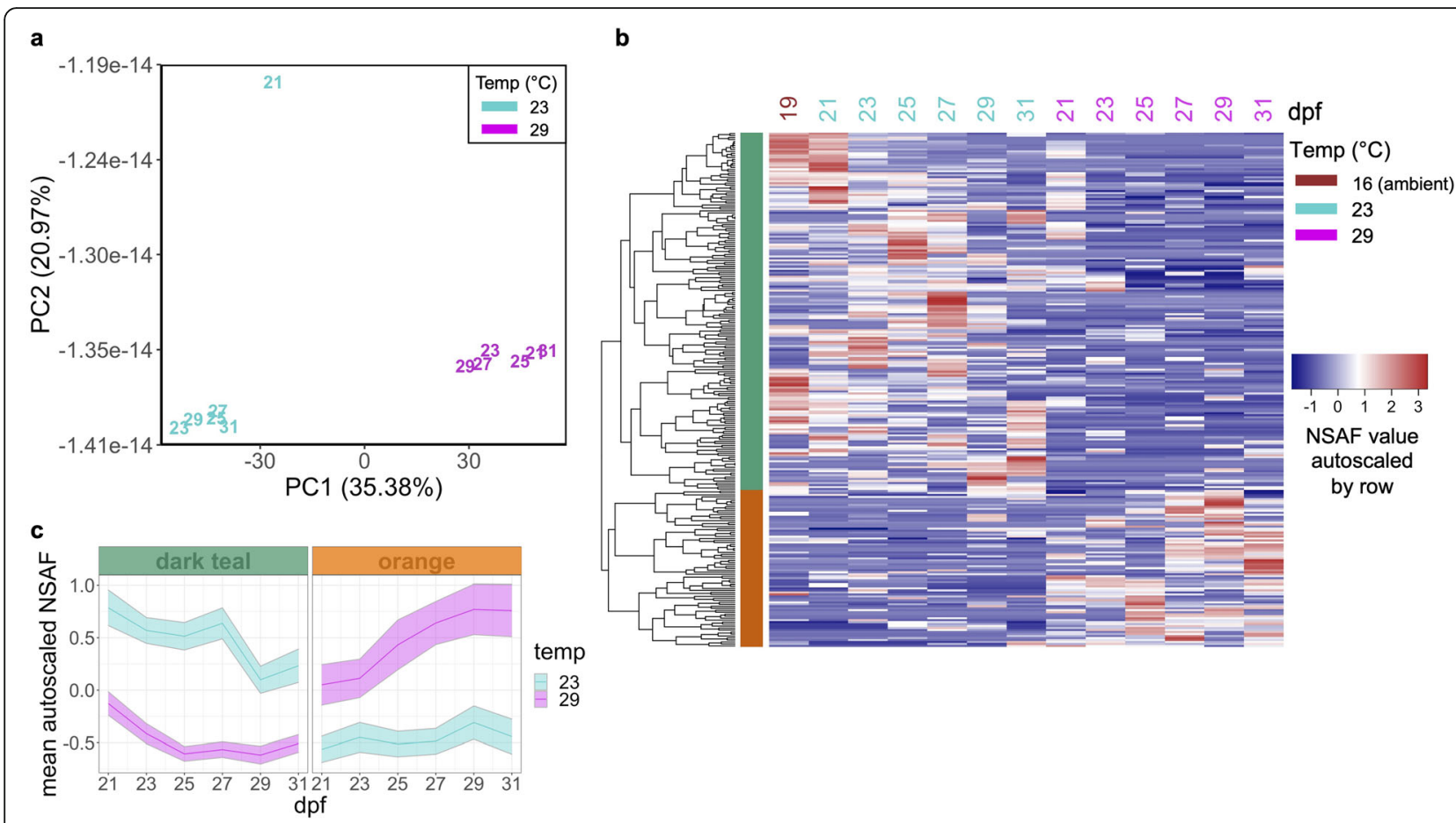

Fig. 5 Temperature influence on proteomes. a Score plot for the temperature factor calculated by ANOVA-simultaneous component analysis of all protein abundances. Samples are labeled by their sampling time point in days post-fertilization (dpf) with color indicating rearing temperature $\left(23^{\circ} \mathrm{C}\right.$, cyan; $29^{\circ} \mathrm{C}$, magenta). b Protein abundances (NSAF values autoscaled by row) of 259 proteins that contributed the most to temperatureinfluenced proteomic variation. c Temporal abundance patterns of 259 temperature-influenced proteins based on 2 clades. Bolded line, autoscaled NSAF clade mean with 95\% confidence intervals shown

were able to identify proteins that most contribute to variation across time points and variation between temperatures. We were able to further classify differentially abundant proteins by performing hierarchical clustering of their abundance patterns and assigning clades to distinct patterns of abundance change over time and across temperatures. This multi-statistical approach led to the identification of proteins with time and temperaturedependent abundance patterns (Figs. 3 and 5), and while we could have been more precise in thresholding PC loadings to select proteins, we chose to be more inclusive as to not limit the scope of this exploratory study. Although time and the interaction of time and temperature explained more of the ASCA-partitioned variation in the proteomes, a permutation validation test revealed time had the greatest effect on protein abundance, followed by temperature, and lastly by the interaction of time and temperature (Table 1). We chose to not examine the time: temperature interaction effect because the permutation validation test suggested our observations were not different than random chance. However, we chose to examine the temperature effect because it was nearer to being significant and examining proteins contributing to ASCApartitioned temperature variation allowed two distinct temperature-dependent abundance patterns to emerge.
The functional analysis carried out here was limited by few bivalve genes and proteins having been functionally characterized, and mostly depended on gene ontology inferences made from annotated proteins in other species that shared protein sequence similarity to $C$. gigas proteins. Moreover, a number of $C$. gigas proteins with potentially crucial roles in metamorphosis that lacked annotations due to low similarity to proteins in other species in the UniProtKB database [28] were excluded from the functional analysis. Thus, the results from the functional analysis generally should be considered with some uncertainty. Nonetheless, through examining proteins contributing to time and temperature variance we were able to provide comprehensive insight into the proteomic landscape throughout oyster development in conjunction with the nuanced influence of temperature.

We found that temperature only moderately affected proteomes, similar to previous findings [22], and that time was a stronger driver of proteomic differences across samples. This is consistent with the concept that gene expression patterns enable underlying physiological programs to be preserved in different environmental conditions in order for oysters to achieve key developmental stages $[22,29,30]$. The five distinct protein abundance trends over time are suggestive of particular 


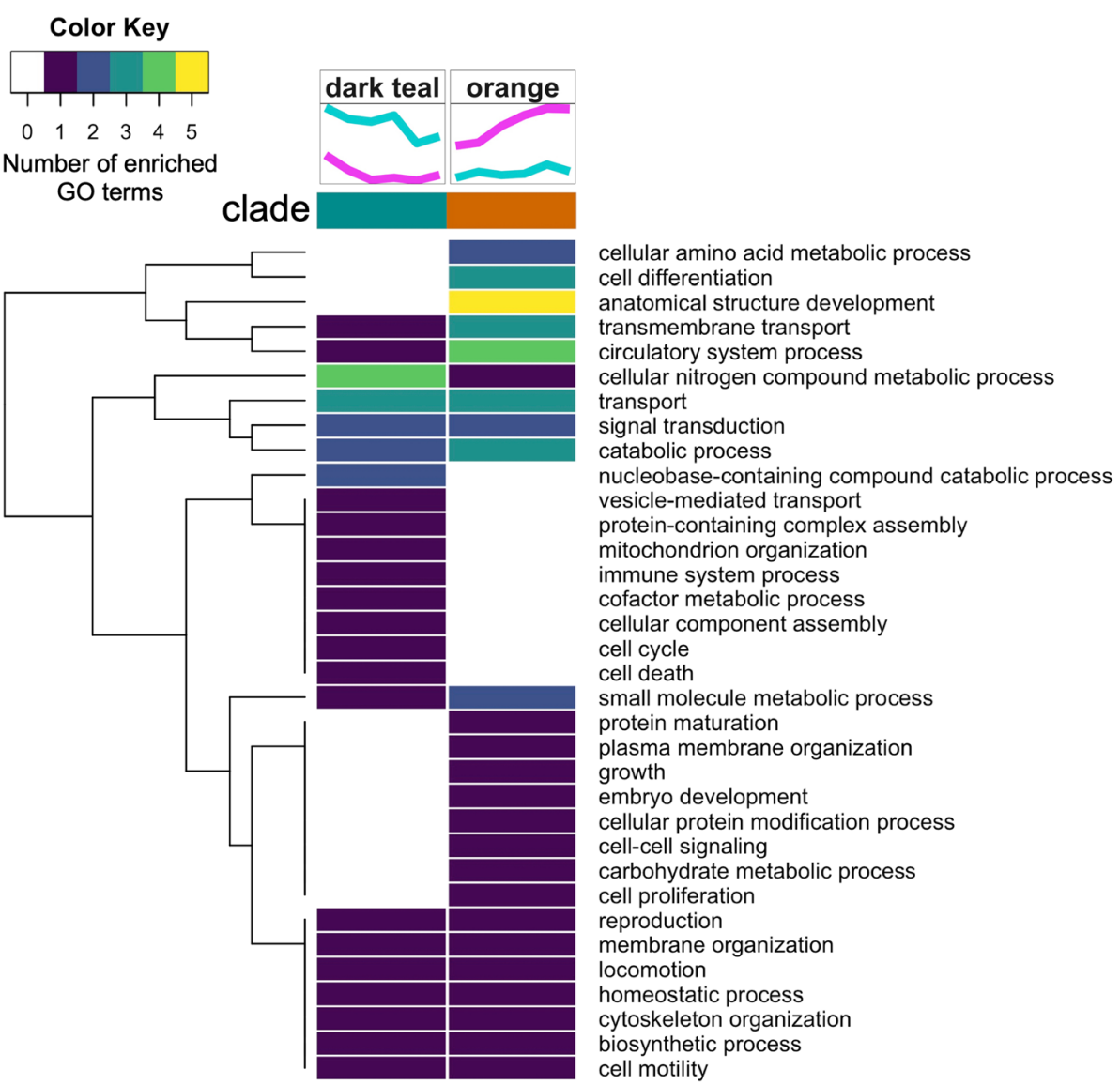

Fig. 6 Summary of biological processes represented by enriched GO terms within each clade for temperature-influenced proteins

developmental processes persisting and remaining in sync despite temperature differences.

During typical development, swimming pediveliger larvae settle around $18 \mathrm{dpf}$, and within 1 to 3 days after settlement most larvae complete metamorphosis to the juvenile stage [5]. In our experiment, 2 days after larvae appeared competent at $21 \mathrm{dpf}$, proteins that had high abundance and were then acutely reduced over time (light blue clade) aligned with larval settlement. Seven of the 42 proteins with Uniprot annotations in this clade, and no proteins from other clades, previously showed pediveliger stage-specific expression (CGI_10004853, CGI_10010615, CGI_10006921, CGI_10026725, CGI_ 10010375, CGI_10006922, and CGI_10006919) [2]. Among other light blue clade proteins were three protease inhibitors, nine structural proteins mostly related to collagen, and five calcification-related proteins that did not previously show pediveliger stage-specific transcript expression, but support hypotheses previously formulated about adhesion during larval settlement [2]. These differences between transcript and protein abundances during settlement highlight the importance of proteomics studies to complement transcriptomics studies.
A key feature of metamorphosis following pediveliger settlement is organ revolution in an anterior-dorsal direction [5]. Proteins that had high abundance at $23 \mathrm{dpf}$ followed by a gradual decrease over time (purple clade) showed clade-specific enrichment of processes related to cell component assembly and protein complex assembly. These included structural proteins (dynein 2 light chain and laminin B2), cell fate determining proproteins (ADAM-TS 16, ADAM-TS 17, and Notch3), and a protein catabolism promoting protein (Cell death regulatory protein GRIM-19), all of which support a tight regulation of growth, cell differentiation and movement that could underlie organ rearrangement at this time point. Moreover, the exosome complex component protein (RRP40) related to the clade-specific enrichment of nucleobasecontaining compound catabolism, tRNA metabolic and ribosome biogenesis related processes may play a role in modulating the abundance of pediveliger-specific and recently metamorphosed juvenile-specific lincRNAs [31].

Metamorphosis from larval to juvenile stage encompasses two opposing processes that occur in synchrony: degradation (e.g. velum and foot degradation) and growth processes (e.g. gill and adductor muscle 
development). We observed two opposing trends in protein abundance patterns over time that were generally unaffected by temperature. Proteins with abundances that increase through $25 \mathrm{dpf}$ then decrease through 29 $\mathrm{dpf}$ and increase again at 31dpf (green clade) showed clade-specific enrichment of protein modification and signal transduction related processes generally related to growth promoting pathways. For instance green clade proteins Map kinase kinase 4, Map kinase kinase 5, and PAK-1 are all members of the MAPK signaling pathway that activates cell differentiation and proliferation, potentially related to the development of gill tissue during the prodissoconch and dissoconch postlarval stages and the development of the adductor muscle in the early juvenile stage [5]. Additionally, proteins underlying cladespecific enrichment of lipid and cofactor metabolic processes include oxidative stress protective enzymes paraoxonase and glucose-6-phosphate dehydrogenase which likely act to counter the reactive oxygen species resulting from the aerobic respiration that metamorphosis requires [5]. Proteins with abundances showing an opposing trend decreasing through $25 \mathrm{dpf}$, then increasing through $29 \mathrm{dpf}$ and decreasing again at 31dpf (gray clade) had clade-specific enrichment of cell-cell signaling and transport processes. These included a protein involved in neurotransmitter release regulation (Snapin), GABA type A receptor-associated protein, Hsc70interacting protein, and a number of cytoskeleton related proteins (Rho1, Tubulin-folding cofactor B, Filamin-B, and muscle actin LpM) involved in growth regulation. The increased abundance of these proteins at 27-29 dpf could serve in signaling the downregulation of processes initiated by the growth-related proteins at 23-25 dpf (green clade). The potential growth-curbing role of the gray clade proteins is further supported by their decreased abundance at $31 \mathrm{dpf}$ and the enrichment of growth promoting and carbohydrate metabolic processes in proteins showing an increase over time peaking at $31 \mathrm{dpf}$ (black clade). At this time point, the high abundance of fatty acid binding proteins (H-FABP and B-FABP), muscle growthrelated proteins (Thymosin beta, Tropomyosin, and Collagen alpha-3 (VI) chain), and carbohydrate metabolic proteins (Hexokinase type 2, Fructose-bisphosphate aldolase, and Ganglioside GM2 activator (involved in the degradation of oligosaccharide-containing gangliosides [32])) is suggestive of muscle tissue building and maintenance (e.g. adductor muscle) that occur after the establishment of structural components, and that the final juvenile stage has been reached.

Although temperature did not have as dominant an effect as time on protein abundances, the two distinct temperature-dependent protein abundance patterns and their associated biological processes support the phenotypic differences we observed in larvae reared at different temperatures. The growth and development-related processes enriched among proteins showing increased abundance in $29^{\circ} \mathrm{C}$ relative to $23^{\circ} \mathrm{C}$ regardless of time suggest a mechanism for the larger sizes observed for animals reared $29^{\circ} \mathrm{C}$ compared to $23^{\circ} \mathrm{C}$ at $24 \mathrm{dpf}$. While larger size could be due to elevated temperature increasing overall development rate [33, 34] by increasing ingestion activity $[13,35]$, we did not detect a significant time:temperature interaction effect. We did, however, observe specific time points where temperature appeared to have a greater impact on protein abundance (21 and $27 \mathrm{dpf}$ ) and thus on timing of key developmental processes. For example, proteins showing increased abundance at $21 \mathrm{dpf}$ (pale yellow clade) related to motility at $23{ }^{\circ} \mathrm{C}$ (e.g. cilia and flagella associated proteins 53, 54, 58 , and 43 , TPR repeat protein 25 , and tektin-4) could indicate the persistence of the velum organ at $23^{\circ} \mathrm{C}$ and its degradation at $29^{\circ} \mathrm{C}$. The decreased abundance of muscle forming proteins, filament proteins, and signaling proteins at $27 \mathrm{dpf}$ in animals reared at $23^{\circ} \mathrm{C}$ (pale purple clade) suggests that muscle formation is less robust at $23^{\circ} \mathrm{C}$ than at $29^{\circ} \mathrm{C}$. Of the 79 proteins showing increased abundance regardless of time in $29^{\circ} \mathrm{C}$ relative to $23^{\circ} \mathrm{C}$ (orange clade), 11 have previously shown increased abundance in response to various $30^{\circ} \mathrm{C}$ conditions in a proteomics study on pediveliger (15-17 dpf) Pacific oyster [22] (Table 2). Nine of these proteins are characterized and are commonly involved in smooth muscle and neuron formation.

The immune system, vesicle transport, and nucleobasecontaining, nitrogen compound catabolic processes associated with proteins showing decreased abundance in animals reared at $29^{\circ} \mathrm{C}$ (dark teal clade) are likely associated with metamorphic differences (e.g. different degradation rates of velum or foot), differences in metabolic rate, differences in pathogen presence or susceptibility, or a combination of these. Seawater pathogen presence and abundance could have been different between temperature treatments since temperature can alter seawater microbiome composition [44]. For instance, ciliates from the genus Orchitophryiadae that infect marine invertebrates [45] have shown an upper thermotolerance limit of $27^{\circ} \mathrm{C}$ [46], and might not have survived at $29^{\circ} \mathrm{C}$ but could have at $23^{\circ} \mathrm{C}$. Moreover, temperature can affect both pathogenicity and host susceptibility. For instance, Pacific oyster juveniles infected with OSHV-1 had significantly higher survival at $29^{\circ} \mathrm{C}$ than $21^{\circ} \mathrm{C}$, potentially because at $29^{\circ} \mathrm{C}$ they are able to alter their physiology to limit viral entry $[47,48]$. Specifically related to the proteomics results, viral recognition protein DEAD box protein 58 and growth inhibition/cell death-related proteins serine-threonine kinase receptor-associated protein and DnaJ-like protein have been implicated in dsRNA exposure response in adult $\mathrm{Pa}-$ cific oyster gill tissue [49]. Larval geoduck proteomic 
Table 2 Proteins that commonly show increased abundance in response to high temperature conditions across proteomics studies

\begin{tabular}{|c|c|c|c|c|}
\hline Protein ID & Uniprot ID & Gene ID & Protein name & Function \\
\hline CHOYP_contig_043280.m.49983 & K1PZS2 & CGl_10005951 & Uncharacterized protein & unknown \\
\hline CHOYP_LOC100705966.1.1.m.45957 & K1QJR4 & CGl_10019738 & Heat shock protein beta-1 & $\begin{array}{l}\text { stress resistance and actin } \\
\text { organization }[36] \text {, regulates } \\
\text { transport of neurofilament } \\
\text { proteins }[36,37]\end{array}$ \\
\hline CHOYP_ADD.3.5.m.17639 & K1PEX5 & CGl_10006848 & Protein hu-li tai shao & $\begin{array}{l}\text { actin assembly, important for } \\
\text { neuromotor function }\end{array}$ \\
\hline CHOYP_LOC100367954.2.2.m.66596 & K1P9U4 & CGI_10005881 & Uncharacterized protein & unknown \\
\hline CHOYP_LOC100375029.6.10.m.36981 & K1QM61 & CGI_10009700 & Uncharacterized protein & $\begin{array}{l}\text { actin monomer binding } \\
\text { [GO:0003785]; actin filament } \\
\text { organization [GO:0007015] }\end{array}$ \\
\hline CHOYP_LOC100375029.8.10.m.60484 & K1QM61 & CGI_10009700 & Uncharacterized protein & $\begin{array}{l}\text { actin monomer binding } \\
\text { [GO:0003785]; actin filament } \\
\text { organization [GO:0007015] }\end{array}$ \\
\hline CHOYP_LOC101173335.4.4.m.49816 & K1PFT9 & CGI_10006016 & Transgelin & $\begin{array}{l}\text { actin cross-linking/gelling } \\
\text { protein in fibroblast and } \\
\text { smooth muscle tissue [38-40] }\end{array}$ \\
\hline CHOYP_NF70.1.4.m.31159 & K1PWQ2 & CGI_10018067 & $60 \mathrm{kDa}$ neurofilament protein & intermediate filament [GO:0005882] \\
\hline CHOYP_RPS24.1.8.m.571 & K1PUV4 & CGI_10001493 & 40 S ribosomal protein S24 & $\begin{array}{l}\text { ribosome [GO:0005840]; structural } \\
\text { constituent of ribosome [GO:0003735] } \\
\text { translation [GO:0006412] }\end{array}$ \\
\hline CHOYP_contig_044078.m.50900 & K1Q086 & CGI_10019530 & Ankyrin-2 & $\begin{array}{l}\text { essential role in localization and } \\
\text { membrane stabilization of ion } \\
\text { transporters in muscle cells }[41,42] \text {, } \\
\text { signal transduction [GO:0007165] }\end{array}$ \\
\hline CHOYP_LOC100696604.1.1.m.40638 & K1QP17 & CGI_10010975 & Caprin-1 & $\begin{array}{l}\text { directly binds mRNA involved in } \\
\text { neuronal synaptic plasticity, cell } \\
\text { proliferation, and migration in } \\
\text { multiple cell types; may regulate } \\
\text { mRNA transport and translation [43] }\end{array}$ \\
\hline
\end{tabular}

response to ciliates similarly showed an increase in immune response proteins including molecular chaperones and reactive oxygen species responders [50]. Reduced abundance of these proteins in animals at $29^{\circ} \mathrm{C}$ suggests they were not sustaining immune and cytoprotection processes, allowing them to reallocate energy to growth [51]. Moreover, potential pathogen exposure in animals reared at $23{ }^{\circ} \mathrm{C}$ could have led to a decline in feeding activity and therefore less growth [51]. A delay in velum degradation in oysters reared at $23{ }^{\circ} \mathrm{C}$ could have led to an immune challenge as the velum in particular has shown susceptibility to infection [52-54]. Temperature influenced proteomic differences could therefore be confounded by differences in seawater microbial composition. With no obvious source of pathogen exposure, further controlled trials are needed to determine the extent to which these specific proteome differences are driven by pathogen presence and abundance differences, metabolic rate differences, and/or specific metamorphic process differences.

\section{Conclusion}

We successfully simultaneously surveyed thousands of proteins to generate comprehensive proteomes from which we were able to identify temporal and temperature-influenced protein abundance patterns. We characterized physiological processes related to proteins showing different abundance patterns that underlie core developmental processes, and that underlie the effects of different temperature regimes. These findings offer high resolution insight into the role of temperature and why oysters may experience high mortality rates during this life transition in both field and culture settings. The proteome resource generated and the temporally mapped physiological processes offer data-driven guidance for further investigating specific metamorphic stage transitions, temperature-related phenotypic differences in mollusc development, and developmental regulation in general. Lastly, the analytical approach taken here provides a foundation for effective shotgun proteomic analyses across a variety of taxa.

\section{Methods}

\section{Larval rearing}

All seawater used for rearing flowed continuously from Dabob Bay, WA at $3 \mathrm{~L} / \mathrm{min}$, filtered to $5 \mu \mathrm{m}$, and was maintained at $\mathrm{pH} 8.4$ by the addition of sodium 
carbonate. Animals were fed T-Isochrysis, Pavlova sp., Nannochloropsis sp., Rhodomonas sp., and Tetraselmis sp. at constant effluent algal densities of 100,000 cells/ $\mathrm{mL}$ throughout the experiment. Crassostrea gigas (triploid) larvae were reared at ambient temperature $\left(16^{\circ} \mathrm{C}\right)$ until they developed eyespots and pedal appendages, and were greater than $250 \mu \mathrm{m}$ in size (pediveliger stage; 19 days post-fertilization). An initial sample of $\sim 12,500$ pediveliger larvae was rinsed with filtered seawater, dried, flash frozen in liquid nitrogen and stored at $80^{\circ} \mathrm{C}$ for proteomics analysis. Approximately one million pediveligers $(20.0 \mathrm{~g})$ were transferred to the experimental rearing system consisting of a silo (46 cm PVC pipe) containing $80 \mathrm{~mL}$ of ground oyster shell $(180-315 \mu \mathrm{m}$ graded microculch) as settlement substrate. Each silo was housed inside a rearing tank with flowing filtered seawater and held at either $23^{\circ} \mathrm{C}$ or $29^{\circ} \mathrm{C}$ for 13 days. Tanks were drained and oysters were rinsed with filtered seawater daily.

\section{Settlement assessment and sampling}

At 24 days post-fertilization, settlement and size were assessed using sorting screens ranging from 450 to $1320 \mu \mathrm{m}$, and any larvae that had not set were removed. Settlement was calculated as the proportion of larvae captured on the sorting screens. At 21, 23, 25, 27, 29, and 31 days post-fertilization (corresponding to days 3 , $5,7,9,11$, and 13 of the experiment, respectively) samples of approximately 12,500 larvae were collected from each of the two temperature regimes $\left(23^{\circ} \mathrm{C}\right.$ or $\left.29^{\circ} \mathrm{C}\right)$ for shotgun proteomics analysis. Larvae were rinsed with filtered seawater, dried, flash frozen in liquid nitrogen and stored at $-80^{\circ} \mathrm{C}$. In total there were 13 samples taken for proteomic analysis, one initial sample from 19 days post-fertilization at ambient temperature $\left(16^{\circ} \mathrm{C}\right)$ and six at each temperature regime throughout development.

\section{Protein sample preparation}

Cell homogenates were prepared by adding $500 \mu \mathrm{L}$ of 50 $\mathrm{mM} \mathrm{NH} \mathrm{NHCO}_{3}$ in $6 \mathrm{M}$ urea to the sample and homogenizing with a pestle directly in the microfuge tube. Samples were centrifuged at $2000 \mathrm{rpm}$ for $5 \mathrm{~min}$ to separate solid shell and tissue fragments from the cellular content fraction (the supernatant), and the supernatant $(150 \mu \mathrm{L})$ was transferred into new tubes. Supernatants were sonicated three times each for $5 \mathrm{~s}$, cooling samples in between sonication rounds using an ethanol and dry ice bath for $5 \mathrm{~s}$. After sonication, sample protein concentrations were determined using a BCA assay kit (Pierce). Protein digestion was carried out by diluting $100 \mu \mathrm{g}$ of protein from each sample with $50 \mathrm{mM} \mathrm{NH}_{4} \mathrm{HCO}_{3}$ in 6 $\mathrm{M}$ urea solution to a final volume of $100 \mu \mathrm{L}$, adding 1.5 $\mathrm{M}$ tris $\mathrm{pH} 8.8(6.6 \mu \mathrm{L})$ and $200 \mathrm{mM}$ tris (2-carboxyethyl)phosphine hydrochloride $(2.5 \mu \mathrm{L})$ and vortexing samples.
Samples were maintained at a basic $\mathrm{pH}>7$ by titrating with sodium hydroxide $(5 \mathrm{~N})$. After incubating samples for $1 \mathrm{~h}$ at $37^{\circ} \mathrm{C}, 20 \mu \mathrm{L}$ of $200 \mathrm{mM}$ iodoacetamide was added, samples were vortexed then incubated for $1 \mathrm{~h}$ at room temperature in the dark. Next, $20 \mu \mathrm{L}$ of $200 \mathrm{mM}$ diothiothreitol was added, samples were vortexed, and incubated for $1 \mathrm{~h}$ at room temperature. Then, $1.65 \mu \mathrm{L}$ LysC (lysyl endopeptidase, Wako) (1:30 enzyme:protein ratio) was added to each sample, samples were vortexed, and incubated for $1 \mathrm{~h}$ at room temperature. Finally, $800 \mu \mathrm{L} 25 \mathrm{mM} \mathrm{NH}_{4} \mathrm{HCO}_{3}, 200 \mu \mathrm{L}$ HPLC grade methanol and $3.3 \mathrm{uL}$ Trypsin (Promega) (1:30 enzyme:protein ratio) were added to each sample, samples were vortexed, and incubated overnight at room temperature. Samples were evaporated using a centrifugal evaporator at $4{ }^{\circ} \mathrm{C}$ to near dryness and stored at $-80^{\circ} \mathrm{C}$. Desalting of samples was done using Macrospin columns (sample capacity 0.03-300 $\mu \mathrm{g}$; The Nest Group, Southborough, MA) following the manufacturer's instructions. Dried peptides were reconstituted in $100 \mu \mathrm{L} \mathrm{3 \%}$ acetonitrile $+0.1 \%$ formic acid and stored at $-80^{\circ} \mathrm{C}$.

\section{Mass spectrometry}

Data-dependent acquisition was performed on an Orbitrap Fusion Lumos Mass Spectrometer (Thermo Scientific) at the University of Washington Proteomics Resource to assess the effect of temperature on proteomic profiles throughout larval development. Technical duplicates for each sample were processed by liquid chromatography coupled to tandem mass spectrometry (LC - MS/MS). Briefly, the analytical column $(20 \mathrm{~cm}$ long) was packed in house with $\mathrm{C} 18$ beads (Dr. Maisch HPLC, Germany, $0.3 \mu \mathrm{m}$ ) with a flow rate of $0.3 \mu \mathrm{L} / \mathrm{min}$. Chromatography was carried out with an increasing ratio of acetonitrile $+0.1 \%$ formic acid (solvent A): water + $0.1 \%$ formic acid (solvent B). The solvent gradient was 5-95\% solvent A over 70 min. Quality-control standards (Pierce Peptide Retention Time Calibration mixture + bovine serum albumin) were analyzed throughout the experiment to ensure consistency of peptide detection and elution times.

\section{Protein identification and quantification}

Mass spectrometer raw files (PRIDE Accession no. PXD013262) were converted to .mzXML format and were searched against a protein sequence database that contained the C. gigas proteome (downloaded from http://gigaton.sigenae.org [26]) and common contaminants (downloaded from the crapOME [55]) using Comet v. 2016.01 rev.2 [56]. The Trans Proteomic Pipeline [57] was then used to calculate statistics associated with peptide-to-protein matches with a peptide probability $p$-value threshold of 0.9. Next, Abacus [58] was used to correlate protein inferences across samples and obtain 
a single protein identification for each peptide. From the Abacus output file, the adjusted normalized spectral abundance factor (NSAF) values (spectral abundance normalized to protein sequence length) were used to compare technical duplicates and biological samples in a principal component analysis (PCA) (Additional File 2: Supplemental Figure 1). For the PCA, NSAF values were $\log 2$ transformed after converting zero values to $0.1(1 / 8$ of the lowest NSAF value). NSAF values from technical replicates were averaged for each protein in all downstream analyses.

\section{Preliminary principal component analysis}

For a preliminary assessment of the overall variability of proteomes, PCA was run on $\log 2$ transformed NSAF values for all samples where NSAF values of zero were converted to 0.1 ( $1 / 8$ of the lowest NSAF value) prior to $\log$ transforming. To identify proteins that most contribute to $\mathrm{PC} 1$ and $\mathrm{PC} 2$ variation, $\mathrm{PC} 1$ and $\mathrm{PC} 2$ protein loadings values were ordered and plotted by greatest magnitude loadings value. For each loadings plot, a threshold was placed at the point of diminishing returns, at the first point with the least visual difference between subsequent loadings values, which for PC1 was a loadings value greater than 0.0236 or less than -0.02355 , and for PC2 was a loadings value greater than 0.0245 or less than - 0.0262 (Additional File 2: Supplemental Figure 2). Proteins with a loadings value magnitude greater than or equal to the thresholds were considered proteins most contributing to variation accounting for temperature differences between samples from 21 and $27 \mathrm{dpf}$.

\section{ANOVA-simultaneous component analysis}

ANOVA-simultaneous component analysis (ASCA) from the $\mathrm{R}$ package MetStat [59] was used to evaluate the effect of time, temperature, and their interaction on protein abundance using the $\log 2$ transformed average NSAF values for all samples. To quantitatively validate the significance of effects estimated by ASCA, a permutation test was performed that randomly reassigned group labels and recalculated the ASCA sum of squares 10,000 times [27]. To identify proteins influenced by time, PC1 and PC2 loadings values of the ASCAgenerated PCA for the time factor were ordered by decreasing magnitude and plotted. For each plot a loadings value threshold was placed at the point of diminishing returns, thresholding at the first point with the least visual difference between subsequent loadings values, which for both PC1 and PC2 was $\geq 0.035$ or $\leq-0.035$ (Additional File 2: Supplemental Figure 3a-d). To identify proteins influenced by temperature, PC1 loadings values of the ASCA-generated PCA for the temperature factor were ordered by decreasing magnitude, plotted, and a threshold was placed at the point of diminishing returns, at the first point with the least visual difference between subsequent loadings values, at $\geq 0.03$ or $\leq-$ 0.025 (Additional File 2: Supplemental Figure 3e-f).

\section{Cluster analysis}

Hierarchical clustering was performed on temperatureinfluenced (identified by PCA or ASCA) and timeinfluenced proteins (identified by ASCA only) using the complete linkage clustering algorithm and Pearson correlation-based distances. Dendrograms generated were cut at the height of 1 for proteins identified as temperature-influenced by PCA, 1.8 for time-influenced proteins identified by ASCA, and 1.5 for temperatureinfluenced proteins identified by ASCA to define clades within each group of proteins. Heatmaps of temperature- and time- influenced proteins with clades shown as a colored sidebar were generated using the $\mathrm{R}$ package Heatmap3 [60] and protein abundance plots were generated using the $\mathrm{R}$ package ggplot2 [61].

\section{Functional enrichment}

To explore the biological processes related to proteins influenced by time and temperature, we performed Gene Ontology (GO) enrichment analysis on the proteins within each clade assigned by the aforementioned cluster analysis. First, to retrieve GO annotations protein sequences from the C. gigas proteome (downloaded from http://gigaton.sigenae.org [26]) were queried against the UniProt protein database (UniProt release 2019_01 [28]), a comprehensive reference set of protein sequences and functional information including GO annotations from thousands of species using BLASTp [62]. The rationale behind using a multi-species reference set as opposed to a species-specific reference set was to obtain functional information for as many proteins as possible where many C. gigas proteins lack annotation and homologs in other species may have annotations. The alignment with the lowest e-value was kept for each protein sequence, and alignments were filtered further for those with an evalue of less than or equal to $1 \times 10^{-10}$ to keep only high confidence alignments. GO annotations from the Uniprot alignments were used for GO enrichment analysis. A Fisher test was performed with TopGO [63] using default settings on proteins from each clade defined by methods described above, using all detected proteins across all samples with $\mathrm{GO}$ annotations in the Uniprot alignments as the background set. GO terms with $P<0.05$ and occuring $\geq 5$ times in the background set were considered significant [64]. Correction for multiple testing was not applied on the resulting $P$ values because the tests were not considered to be independent [65]. Significant GO terms were converted to GO Slim terms using the R package GSEAbase [66], and heatmaps 
were generated using the heatmap. 2 function in the $R$ package gplots [67].

\section{Comparison to published datasets}

Proteins influenced by time and temperature were compared to genes and proteins previously identified in other C. gigas proteomics studies exploring thermal impact on pediveliger stage [22] and an in silico transcriptomic study of larval settlement [2] using their Uniprot identifiers. Because the Uniprot identifiers in these published datasets were from only the C. gigas species, C. gigas Uniprot identifiers were retrieved for temperature- and time-influenced proteins by aligning their protein sequences from the $C$. gigas proteome (downloaded from http://gigaton.sigenae. org, https://paperpile.com/c/nZgqA5/gwqc [26]) to the species-specific $C$. gigas reference proteome from Uniprot database ('UP000005408_29159') using BLASTp, keeping only the alignment with the lowest e-value for each protein sequence. Alignments were filtered for those with an evalue of less than or equal to $1 \times 10^{-10}$ to keep only high confidence alignments. For temperature-influenced proteins that previously were identified and showed increased abundance in pediveliger proteomes arising from various heat exposure conditions https://paperpile.com/c/nZgqA5/ $\mathrm{XTyBV}$ [22], functional information was retrieved from querying the Uniprot knowledgebase https://paperpile. com/c/nZgqA5/wNixK [28] with their Uniprot identifiers using the Retrieve/ID mapping tool.

\section{Supplementary information}

Supplementary information accompanies this paper at https://doi.org/10 1186/s12864-020-07127-3.

Additional file $\mathbf{1}$ Table S1. Biovolume of oyster seed $(\mathrm{mL})$ settled after 6 days of exposure to high temperatures Data and plot of oyster counts and size measurements for Fig. $1 \mathrm{~b}$.

Additional file 2 Supplemental_Figures. PCA of all technical replicate samples. Figure S1. PCA of all technical replicate samples. Figure S2. Preliminary principal component analysis plots of PC loadings for the top 100 ranked proteins. Figure S3. ANOVA-simultaneous component analysis plots of PC loadings for all proteins.

Additional file $\mathbf{3}$ Table S2. Preliminary proteome characterization. Data and plot showing overlap between different temperature proteomes at each timepoint for Fig. 1C.

Additional file 4 Table S3. PCA, hierarchical clustering, and functional analysis results for all detected proteins. PCA, hierarchical clustering, and functional analysis results for all detected proteins.

Additional file $\mathbf{5}$ Table S4. ASCA time effect analysis, hierarchical clustering, and functional analysis results for all detected proteins. ASCA time effect analysis, hierarchical clustering, and functional analysis results for all detected proteins.

Additional file 6 Table S5. ASCA temperature effect analysis, hierarchical clustering, and functional analysis results for all detected proteins. ASCA temperature effect analysis, hierarchical clustering, and functional analysis results for all detected proteins.

\section{Abbreviations}

ADAM-TS: A disintegrin and metalloproteinase with thrombospondin motifs; ANOVA: Analysis of variance; ASCA: ANOVA-simultaneous component analysis; BCA: Bicinchoninic acid assay; COMMD9: Copper metabolism MURR1 domain-containing protein 9; DEAD box: Family of proteins containing a motif with the amino acid sequence asp-glu-ala-asp; dpf: Day postfertilization; dsRNA: Double stranded ribonucleic acid; FABP: Fatty acidbinding protein; GABA: Gamma aminobutyric acid; GO: Gene ontology; GRIM-19: Gene associated with retinoid-IFN-induced mortality; Hcs70: Heat shock cognate protein 70; LC-MS/MS: Liquid chromatography coupled tandem mass spectrometry; lincRNA: Long intergenic noncoding RNA; MAPK: Mitogen-activated protein kinase; NSAF: Normalized spectral abundance factor; PAK1: p21-activating kinase 1; PCA: Principal component analysis; PVC: Polyvinyl chloride; RNA: Ribonucleic acid; RRP40: Ribosomal RNA-processing protein 40; TPR repeat: Tetratricopeptide repeat; tRNA: Transfer ribonucleic acid

\section{Acknowledgements}

We thank the Taylor Shellfish Hatchery for providing the animals, water treatment, rearing systems, and husbandry. We also thank the current and former members of the Roberts lab at the University of Washington as well as the University of Washington's Proteomics Resource (UWPR95794).

\section{Authors' contributions}

S.B.R., B.V., and B.E. conceived the project. S.B.R., B.V., and B.E. advised research. R.E.T. and E.B.T.S. performed experiments. R.E.T. and S.B.R. performed proteomics analysis. S.A.T. performed statistical analyses with help from K.R.M. S.A.T. performed functional analyses. S.A.T. prepared the manuscript with edits from S.B.R., B.V., K.R.M., and E.B.T.S. The author(s) read and approved the final manuscript.

\section{Funding}

This material is based upon work supported by the Washington Sea Grant award NA140AR4170078; project R/SFA-8, and by a gift of the Washington Research Foundation to the University of Washington eScience Institute.

\section{Availability of data and materials}

Mass spectrometry proteomics data (.raw, pepxml, and .mzXML files) have been deposited to the ProteomeXchange Consortium via the PRIDE (PubMed ID: 30395289) partner repository with the dataset identifier PXD013262. Additional files, additional supporting materials, and code is available at https://doi.org/10.6084/m9.figshare.12436598.

\section{Ethics approval and consent to participate}

Not applicable.

\section{Consent for publication}

Not applicable

\section{Competing interests}

The authors declare that they have no competing interests.

\section{Author details}

${ }^{1}$ School of Aquatic and Fishery Sciences, University of Washington, Seattle, Washington 98105, USA. ${ }^{2}$ Taylor Shellfish Hatchery, Quilcene, Washington, USA. ${ }^{3}$ Washington Sea Grant, University of Washington, Seattle, Washington, USA. ${ }^{4}$ Department of Genome Sciences, University of Washington, Seattle, Washington, USA.

Received: 6 July 2020 Accepted: 8 October 2020

Published online: 19 October 2020

\section{References}

1. Food and Agriculture Organization of the United Nations. FAO Yearbook. Fishery and Aquaculture Statistics 2017/FAO annuaire. Food \& Agriculture Org.; 2019. https://books.google.com/books/about/FAO_Yearbook_Fishery_ and_Aquaculture_Sta.html?hl=\&id=WC2rDwAAQBAJ.

2. Foulon V, Boudry P, Artigaud S, Guérard F, Hellio C. In Silico Analysis of Pacific Oyster (Crassostrea gigas) Transcriptome over Developmental Stages Reveals Candidate Genes for Larval Settlement. Int J Mol Sci. 2019;20. https://doi.org/10.3390/ijms20010197.

3. Coon SL, Fitt WK, Bonar DB. Competence and delay of metamorphosis in the Pacific oyster Crassostrea gigas. Marine Biology. 1990:379-87. https://doi. org/10.1007/bf01344316. 
4. Plough LV. Fine-scale temporal analysis of genotype-dependent mortality at settlement in the Pacific oyster Crassostrea gigas. J Exp Marine Biol Ecol. 2018:501:90-8. https://doi.org/10.1016/j.jembe.2018.01.006.

5. Baker SM, Mann R. Description of metamorphic phases in the oyster Crassostrea virginica and effects of hypoxia on metamorphosis. Marine Ecol Progress Series. 1994:91-9. https://doi.org/10.3354/meps104091.

6. Joyce A, Vogeler S. Molluscan bivalve settlement and metamorphosis: Neuroendocrine inducers and morphogenetic responses. Aquaculture. 2018: 64-82. https://doi.org/10.1016/j.aquaculture.2018.01.002.

7. Quayle DB. Pacific oyster culture in British Columbia. Dept. of Fisheries and Oceans; 1988

8. Korringa P. Farming the Cupped Oysters of the Genus Crassostrea: A Multidisciplinary Treatise: Elsevier Science Limited; 1976. https://books. google.com/books/about/Farming_the_Cupped_Oysters_of_the_Genus. html?hl=\&id=jVYYAQAAIAAJ.

9. Kobayashi M, Hofmann EE, Powell EN, Klinck JM, Kusaka K. A population dynamics model for the Japanese oyster, Crassostrea gigas. Aquaculture. 1997:285-321. https://doi.org/10.1016/s0044-8486(96)01456-1.

10. Helm MM, Bourne N. Hatchery Culture of Bivalves: A Practical Manual. Food \& Agriculture Org; 2004. https://books.google.com/books/about/Hatchery_ Culture_of_Bivalves.html?hl=\&id=hFUbAQAAIAAJ.

11. Ghaffari H, Wang W, Li A, Zhang G, Li L. Thermotolerance Divergence Revealed by the Physiological and Molecular Responses in Two Oyster Subspecies of in China. Front Physiol. 2019;10:1137. https://doi.org/10.3389/ fphys.2019.01137.

12. Food and Agriculture Organization (FAO). Cultured Aquatic Species Fact : Crassostrea gigas. Cultured Aquatic Species Information Programme. Text by Helm, M.M. In: FAO Fisheries Division [online]. Food \& Agriculture Org; 2009. https://books.google.com/books/about/Cultured_Aquatic_Species_ Fact_Sheets.html?hl=\&id=DjdBtAEACAAJ.

13. Rico-Villa B, Pouvreau S, Robert R. Influence of food density and temperature on ingestion, growth and settlement of Pacific oyster larvae, Crassostrea gigas. Aquaculture. 2009:395-401 https://doi.org/10.1016/j. aquaculture.2008.10.054.

14. His $E$, Robert R, Dinet A. Combined effects of temperature and salinity on fed and starved larvae of the mediterranean mussel Mytilus galloprovincialis and the Japanese oyster Crassostrea gigas. Marine Biol. 1989:455-63. https:// doi.org/10.1007/bf00394822.

15. Helm MM, Millican PF. Experiments in the hatchery rearing of Pacific oyster larvae (Crassostrea gigas Thunberg). Aquaculture. 1977:1-12. https://doi.org/ 10.1016/0044-8486(77)90149-1.

16. Crandall GA, Elliott Thompson R, Eudeline B, Vadopalas B, TimminsSchiffman E, Roberts SB. Proteomic response of early juvenile Pacific oysters to temperature; 2020.

17. Casas-Vila N, Bluhm A, Sayols S, Dinges N, Dejung M, Altenhein T, et al. The developmental proteome of Drosophila melanogaster. Genome Res. 2017; 27:1273-85. https://doi.org/10.1101/gr.213694.116.

18. Griffin NM, Yu J, Long F, Oh P, Shore S, Li Y, et al. Label-free, normalized quantification of complex mass spectrometry data for proteomic analysis. Nat Biotechnol. 2010;28:83-9. https://doi.org/10.1038/nbt.1592.

19. Huan P, Wang H, Dong B, Liu B. Identification of differentially expressed proteins involved in the early larval development of the Pacific oyster Crassostrea gigas. J Proteomics. 2012;75:3855-65. https://doi.org/10.1016/j. jprot.2012.04.051.

20. Timmins-Schiffman E, Guzmán JM, Elliott Thompson R, Vadopalas B, Eudeline B, Roberts SB. Dynamic response in the larval geoduck (Panopea generosa) proteome to elevated pCO2. Ecol Evol. 2019;10:185-97. https:// doi.org/10.1002/ece3.5885.

21. Huan P, Wang H, Liu B. A Label-Free Proteomic Analysis on Competent Larvae and Juveniles of the Pacific Oyster Crassostrea gigas. PLoS One. 2015; 10:e0135008. https://doi.org/10.1371/journal.pone.0135008.

22. Dineshram R, Chandramouli K, Ko GWK, Zhang H, Qian P-Y, Ravasi T, et al. Quantitative analysis of oyster larval proteome provides new insights into the effects of multiple climate change stressors. Glob Chang Biol. 2016;22: 2054-68. https://doi.org/10.1111/gcb.13249.

23. Grissa D, Pétéra M, Brandolini M, Napoli A, Comte B, Pujos-Guillot E. Feature Selection Methods for Early Predictive Biomarker Discovery Using Untargeted Metabolomic Data. Front Mol Biosci. 2016;3:30. https://doi.org/ 10.3389/fmolb.2016.00030.

24. Trigg SA, McElhany P, Maher M, Perez D, Busch DS, Nichols KM. Uncovering mechanisms of global ocean change effects on the Dungeness crab
(Cancer magister) through metabolomics analysis. Sci Rep. 2019;9:10717. https://doi.org/10.1038/s41598-019-46947-6.

25. Smilde AK, Jansen JJ, Hoefsloot HCJ, R-J A, van der Greef J, Timmerman ME. ANOVA-simultaneous component analysis (ASCA): a new tool for analyzing designed metabolomics data. Bioinformatics. 2005:3043-8. https://doi.org/ 10.1093/bioinformatics/bti476.

26. Riviere G, Klopp C, Ibouniyamine N, Huvet A, Boudry P, Favrel P. GigaTON: an extensive publicly searchable database providing a new reference transcriptome in the pacific oyster Crassostrea gigas. BMC Bioinformatics. 2015;16:401. https://doi.org/10.1186/s12859-015-0833-4.

27. Zwanenburg G, Hoefsloot HCJ, Westerhuis JA, Jansen JJ, Smilde AK. ANOVAprincipal component analysis and ANOVA-simultaneous component analysis: a comparison. Journal of Chemometrics. 2011:561-7. https://doi. org/10.1002/cem.1400

28. The UniProt Consortium. UniProt: a worldwide hub of protein knowledge. Nucleic Acids Research. 2019:D506-15. https://doi.org/10.1093/nar/gky1049.

29. Meistertzheim A-L, Tanguy A, Moraga D, Thébault M-T. Identification of differentially expressed genes of the Pacific oyster Crassostrea gigas exposed to prolonged thermal stress. FEBS J. 2007;274:6392-402. https://doi. org/10.1111/j.1742-4658.2007.06156.x.

30. Ginger KWK, Vera CBS, R D, Dennis CKS, Adela LJ, Yu Z, et al. Larval and post-larval stages of Pacific oyster (Crassostrea gigas) are resistant to elevated CO2. PLoS One. 2013;8:e64147. https://doi.org/10.1371/journal. pone.0064147

31. Yu H, Zhao X, Li Q. Genome-wide identification and characterization of long intergenic noncoding RNAs and their potential association with larval development in the Pacific oyster. Sci Rep. 2016;6:20796. https://doi.org/10. 1038/srep20796.

32. Sandhoff $R$, Sandhoff K. Emerging concepts of ganglioside metabolism. FEBS Lett. 2018;592:3835-64. https://doi.org/10.1002/1873-3468.13114.

33. O'Connor MI, Bruno JF, Gaines SD, Halpern BS, Lester SE, Kinlan BP, et al. Temperature control of larval dispersal and the implications for marine ecology, evolution, and conservation. Proc Nat Acad Sci. 2007:1266-71. https://doi.org/10.1073/pnas.0603422104.

34. Filgueira R, Brown MS, Comeau LA, Grant J. Predicting the timing of the pediveliger stage of Mytilus edulis based on ocean temperature. J Molluscan Studies. 2015:269-73. https://doi.org/10.1093/mollus/eyu093.

35. Humphries S. A physical explanation of the temperature dependence of physiological processes mediated by cilia and flagella. Proc Natl Acad Sci U S A. 2013;110:14693-8. https://doi.org/10.1073/pnas.1300891110.

36. Kostenko S, Johannessen M, Moens U. PKA-induced F-actin rearrangement requires phosphorylation of Hsp27 by the MAPKAP kinase MK5. Cell Signal. 2009;21:712-8. https://doi.org/10.1016/j.cellsig.2009.01.009.

37. Holmgren A, Bouhy D, De Winter V, Asselbergh B, Timmermans J-P, Irobi J, et al. Charcot-Marie-Tooth causing HSPB1 mutations increase Cdk5mediated phosphorylation of neurofilaments. Acta Neuropathol. 2013;126: 93-108. https://doi.org/10.1007/s00401-013-1133-6.

38. Matsui TS, Ishikawa A, Deguchi S. Transgelin-1 (SM22a) interacts with actin stress fibers and podosomes in smooth muscle cells without using its actin binding site. Biochem Biophys Res Commun. 2018;505:879-84. https://doi. org/10.1016/j.bbrc.2018.09.176.

39. Thweatt R, Lumpkin CK Jr, Goldstein S. A novel gene encoding a smooth muscle protein is overexpressed in senescent human fibroblasts. Biochem Biophys Res Commun. 1992;187:1-7. https://doi.org/10.1016/s0006291x(05)81449-4.

40. Assinder SJ, Stanton J-AL, Prasad PD. Transgelin: an actin-binding protein and tumour suppressor. Int J Biochem Cell Biol. 2009;41:482-6. https://doi. org/10.1016/j.biocel.2008.02.011.

41. Cunha SR, Bhasin N, Mohler PJ. Targeting and stability of Na/Ca exchanger 1 in cardiomyocytes requires direct interaction with the membrane adaptor ankyrin-B. J Biol Chem. 2007;282:4875-83. https://doi.org/10.1074/jbc.M607096200.

42. Mohler PJ, Schott J-J, Gramolini AO, Dilly KW, Guatimosim S, duBell WH, et al. Ankyrin-B mutation causes type 4 long-QT cardiac arrhythmia and sudden cardiac death. Nature. 2003;421:634-9. https://doi.org/10.1038/ nature01335.

43. Solomon S, Xu Y, Wang B, David MD, Schubert P, Kennedy D, et al. Distinct structural features of caprin-1 mediate its interaction with G3BP-1 and its induction of phosphorylation of eukaryotic translation initiation factor 2alpha, entry to cytoplasmic stress granules, and selective interaction with a subset of mRNAs. Mol Cell Biol. 2007:27:2324-42. https://doi.org/10.1128/ MCB.02300-06. 
44. Lopez-Joven C, Rolland J-L, Haffner P, Caro A, Roques C, Carré C, et al. Oyster Farming, Temperature, and Plankton Influence the Dynamics of Pathogenic Vibrios in the Thau Lagoon. Front Microbiol. 2018;9:2530. https://doi.org/10.3389/fmicb.2018.02530.

45. Elston RA, Cheney D, Frelier P, Lynn D. Invasive orchitophryid ciliate infections in juvenile Pacific and Kumomoto oysters, Crassostrea gigas and Crassostrea sikamea. Aquaculture. 1999:1-14. https://doi.org/10.1016/s00448486(98)00512-2.

46. Stickle WB, Kozloff EN, Story S. Physiology of the ciliate Orchitophrya stellarum and its experimental infection of Leptasterias spp. Canadian Journal of Zoology. 2007:201-6. https://doi.org/10.1139/z06-211.

47. Delisle L, Petton B, Burguin JF, Morga B, Corporeau C, Pernet F. Temperature modulate disease susceptibility of the Pacific oyster Crassostrea gigas and virulence of the Ostreid herpesvirus type 1. Fish Shellfish Immunol. 2018;80: 71-9. https://doi.org/10.1016/j.fsi.2018.05.056.

48. Delisle L, Pauletto M, Vidal-Dupiol J, Petton B, Bargelloni L, Montagnani C, et al. High temperature induces transcriptomic changes in Crassostrea gigas that hinders progress of Ostreid herpesvirus (OsHV-1) and promotes survival. J Exp Biol. 2020. https://doi.org/10.1242/jeb.226233.

49. Masood M, Raftos DA, Nair SV. Two Oyster Species That Show Differential Susceptibility to Virus Infection Also Show Differential Proteomic Responses to Generic dsRNA. J Proteome Res. 2016;15:1735-46. https://doi.org/10. 1021/acs.jproteome.5b00615.

50. Timmins-Schiffman E, Guzmán JM, Elliott Thompson R, Vadopalas B, Eudeline B, Roberts SB. Larval Geoduck (Panopea generosa) Proteomic Response to Ciliates. Sci Rep. 2020;10:6042. https://doi.org/10.1038/s41598020-63218-X.

51. Genard B, Miner P, Nicolas J-L, Moraga D, Boudry P, Pernet F, et al. Integrative Study of Physiological Changes Associated with Bacterial Infection in Pacific Oyster Larvae. PLoS ONE. 2013:e64534. https://doi.org/10. 1371/journal.pone.0064534.

52. Ushijima B, Richards GP, Watson MA, Schubiger CB, Häse CC. Factors affecting infection of corals and larval oysters by Vibrio coralliilyticus. PLoS One. 2018;13:e0199475. https://doi.org/10.1371/journal.pone.0199475.

53. Estes RM, Friedman CS, Elston RA, Herwig RP. Pathogenicity testing of shellfish hatchery bacterial isolates on Pacific oyster Crassostrea gigas larvae. Dis Aquat Organ. 2004;58:223-30. https://doi.org/10.3354/dao058223.

54. Renault T, Novoa B. Viruses infecting bivalve molluscs. Aquatic Living Resources. 2004:397-409. https://doi.org/10.1051/alr:2004049.

55. Mellacheruvu D, Wright Z, Couzens AL, Lambert J-P, St-Denis NA, Li T, et al. The CRAPome: a contaminant repository for affinity purification-mass spectrometry data. Nat Methods. 2013;10:730-6. https://doi.org/10.1038/ nmeth.2557.

56. Eng JK, Jahan TA, Hoopmann MR. Comet: an open-source MS/MS sequence database search tool. Proteomics. 2013;13:22-4. https://doi.org/10.1002/ pmic.201200439.

57. Deutsch EW, Mendoza L, Shteynberg D, Farrah T, Lam H, Tasman N, et al. A guided tour of the Trans-Proteomic Pipeline. Proteomics. 2010;10:1150-9. https://doi.org/10.1002/pmic.200900375.

58. Fermin D, Basrur V, Yocum AK, Nesvizhskii Al. Abacus: a computational tool for extracting and pre-processing spectral count data for label-free quantitative proteomic analysis. Proteomics. 2011;11:1340-5. https://doi.org/ 10.1002/pmic.201000650.

59. Dorscheidt T. MetStaT: Statistical metabolomics tools. 2013. https://CRAN.Rproject.org/package $=$ MetStaT.

60. Zhao S, Guo Y, Sheng Q, Shyr Y. Heatmap3: an improved heatmap package with more powerful and convenient features. BMC Bioinformatics. 2014:P16. https://doi.org/10.1186/1471-2105-15-s10-p16.

61. Wickham H. ggplot2: Elegant Graphics for Data Analysis. Springer-Verlag New York; 2016

62. Altschul SF, Gish W, Miller W, Myers EW, Lipman DJ. Basic local alignment search tool. J Mol Biol. 1990;215:403-10. https://doi.org/10.1016/S00222836(05)80360-2.

63. Alexa A RJ. topGO: Enrichment Analysis for Gene Ontology. 2019. https:// bioconductor.org/packages/release/bioc/html/topGO.html.

64. Li Y, Liew YJ, Cui G, Cziesielski MJ, Zahran N, Michell CT, et al. DNA methylation regulates transcriptional homeostasis of algal endosymbiosis in the coral model Aiptasia. Sci Adv. 2018:4:eaat2142. https://doi.org/10.1126/ sciadv.aat2142.

65. Alexa A, Rahnenführer J, Lengauer T. Improved scoring of functional groups from gene expression data by decorrelating GO graph structure.
Bioinformatics. 2006;22:1600-7. https://doi.org/10.1093/bioinformatics/ btl140.

66. Morgan M, Falcon S, and Gentleman R. GSEABase: Gene set enrichment data structures and methods. 2018. https://bioconductor.org/packages/ release/bioc/html/GSEABase.html.

67. Warnes GR, Bolker B, Bonebakker L, Gentleman R, Huber W, Liaw A, et al. gplots: Various R Programming Tools for Plotting Data. 2019. https://CRAN. R-project.org/package $=$ gplots.

\section{Publisher's Note}

Springer Nature remains neutral with regard to jurisdictional claims in published maps and institutional affiliations.
Ready to submit your research? Choose BMC and benefit from:

- fast, convenient online submission

- thorough peer review by experienced researchers in your field

- rapid publication on acceptance

- support for research data, including large and complex data types

- gold Open Access which fosters wider collaboration and increased citations

- maximum visibility for your research: over $100 \mathrm{M}$ website views per year

At BMC, research is always in progress.

Learn more biomedcentral.com/submissions 